\title{
WESTERN UKRAINE IN THE CONTEXT OF DISINTEGRATION AND INTEGRATION PROCESSES DURING THE 1930S-1940S (HISTORICAL AND LEGAL ASPECT)
}

\author{
ANDRIY REDKO
}

\begin{abstract}
In this article the disintegration and integration processes in Central and Eastern Europe and their influence on the legal status of Western Ukraine are researched. Disintegration correlates with the Soviet occupation of Western Ukraine, and integration correlates with the process of its joining the USSR. The historical and legal dimension of Ukraine in the European context is conceptualized by distinguishing the stages of these processes.
\end{abstract}

Keywords: Western Ukraine, Poland, USSR, disintegration, integration, legal status.

At the current stage of development, Ukraine is on the way to the European integration. By doing so, it restores historical justice, since a part of the ethnic Ukrainian lands belonged to Poland and Romania, and was culturally influenced by them. However, the World War II radically changed this geopolitical situation.

Western Ukraine in the 1930's and 1940's was simultaneously involved in both the disintegration processes during the Soviet Union occupation of the parts of the ethnic Ukrainian lands on the territories of Poland, and the integration processes during the period of the Western Ukrainian lands becoming part of the USSR.

Researching the political and legal grounds of the administrative-territorial changes in Western Ukraine and their international and legal consolidation during the World War II, it should be emphasized that the territory of Western Ukrainian at the beginning of the World War II, specifically 1920-1939, was divided among three countries: Poland, Romania, Czechoslovakia [1, p. 36].

Majority of the Western Ukrainian territory was a part of Poland (139.3 thousand sq. km, 8.3 million people). Due to the administrative-territorial division, it was divided into the following provinces: Polissia (without two districts) - 37,462 sq. km, 879 thousand people, according to the census of 1921; Volyn - 30228 sq. km, 1438 thousand people; Lviv - 27024 thousand sq. km, 2718 thousand people; Stanislaviv - 18468 sq. km, 1339 thousand people; Ternopil - 16240 sq. km, 1428 thousand people; Lublin (6 Ukrainian districts of the Kholm region) - 9984 sq. km, 520 thousand people [2, p. 332]. Five provinces - Volyn, Lviv, Polissia, Stanislaviv, and Ternopil - all together they comprised 35\% of the territory and $30 \%$ of the population of Poland [3, p. 223].

In September 1939 the borders of Poland were $5529 \mathrm{~km}$ long, including $1912 \mathrm{~km}$ of the border with Germany, 1,412 km of the border with theSoviet Union, $984 \mathrm{~km}$ of the border with Czechoslovakia, 507 
$\mathrm{km}$ of the border with Lithuania, $347 \mathrm{~km}$ of the border with Romania, and $121 \mathrm{~km}$ of the border with the Free City of Gdańsk, and $106 \mathrm{~km}$ of the border with Latvia, with the fact that the sea border was 140 $\mathrm{km}$. However, only the borders with Romania and Latvia, as well as the maritime boundary, did not cause controversy [4, p. 77]. Due to the territorial disputes, Poland was included in the circle of influence of Eastern Europe. On the 23rd of August 1939, a Soviet-German non-aggression treaty was signed in Moscow.

The result of the implementation of one of the conditions of the secret protocol to the SovietGerman Non-Aggression Pact from the $23^{\text {rd }}$ of August 1939, according to which western lands of Ukraine to the River San were included into the circle of influence of the USSR, was that on the $17^{\text {th }}$ of September 1939, parts of the Red Army crossed the Polish-Soviet border and soon occupied the territory of Eastern Galicia.

The Red Army attack, planned in advance by Stalinist leadership, was unexpected for the Poles, the amount of active labor and equipment involved in this company, the volume of military mobilization, the large area of the military operations (almost $200 \mathrm{sq} . \mathrm{km}$ ), and, finally, the tight interaction of the connections of the Red Army with the Wehrmacht played a fundamental role in the demoralization and the final defeat of the Polish armed forces and the fall of the Polish state. Consequen tly, the proclaimed German-Polish and undeclared Soviet-Polish wars became components of a unified process of the "fourth division of Poland" and the beginning of the World War II [5, p. 342].

According to V.S. Makarchuk, the entry of the Soviet troops to the territory of Eastern Poland in a legal sense is justified, based on the view of the need to protect the vital interests of the USSR, the apparent aggressiveness and unpredictability of the behavior of Hitler's leadership. The RibbentropMolotov Pact could not be regarded as an effective peace guarantee. V.S. Makarchuk reminds us that Hitler had had exactly the same pact with Poland, torn apart by Berlin just four months before the World War II [4, p. 115].

Overall, during the Soviet-Polish war, the Red Army moved forward to the west from the old Soviet borders at the distance of 250 to $350 \mathrm{~km}$ [5, p. 348].

The border on the Bug meant that the Soviet side refused from having the territory of the Warsaw and Lublin provinces inhabited by the Poles. For this, Germany refused from Lithuania, which became a circle of interests of the USSR [6, p. 27].

At the end of October 1939, the border troops of the NKVD of the Ukrainian SSR and the Belarusian SSR were commanded to set up a secure at a new western border of the USSR in a short time and ensure proper order there. At the same time, it was proposed to study carefully the locality and population both in its border zone and on the opposite side, to set up the simplest technical barriers, to introduce the border service with the reinforced units, to organize secret service and military intelligence [7, p. 114].

The process of demarcation of the border between the USSR and Germany on the ground lasted several months and was very coherent. The German military did not prevent topographical surveys of Soviet specialists and demarcation of the border, which took place in the autumn and winter periods. On the $27^{\text {th }}$ of February 1940, according to the Central mixed (USSR and Germany) Border Commission, the establishment of the border signs for almost $1500 \mathrm{~km}$ of the Soviet-German border was completed. In total, almost 2820 border posts were installed [7, p. 114].

The entry of the Red Army to the territory of Eastern Poland in 1939 was accompanied by the creation of legitimate grounds for the introduction of the Soviet regime and sovietisation of the western Ukrainian lands [8, p. 349].

On the $6^{\text {th }}$ of October 1939, the Military Council of the Ukrainian Front, in accordance with the resolution of the Central Committee of the All-Union Communist Party established from the $1^{\text {st }}$ of October 1939, the 22 ${ }^{\text {nd }}$ of October as the day of elections to the National Assembly of Western Ukraine, as well as the day of their convocation on the $26^{\text {th }}$ of October 1939. At the same time, the Military Council approved the "Directive on the elections to the Ukrainian Assembly of Western Ukraine", according to which the elections were to be held on the basis of general, equal, direct election law, by secret voting on a single official list. The same council approved the Election Committee. It consisted of: 
M. G. Matsko - head, V. D. Maliukh - Deputy, P. I. Lukin - secretary, members of the committee M. S. Grechukha, O. S. Korniichuk, M. V. Grulenko, L. S. Gryshchuk, V. A. Begma, F. I. Eremenko, S. M. Gorbatenko, A. E. Karmazyn, Y. F. Zavadka, I. A. Soroka, M. N. Didek, V. M. Bilan, M. I. Pancyshyn, V. O. Barvinskyi. Of the 17 committee members, only 8 were from Western Ukraine. The direct organizers of the preparation and conduction of the elections were workers sent from Moscow and Kyiv. Therefore, from Moscow to Western Ukraine, 1,000 communists and 500 komsomol members were directed. The Central Committee of the Communist Party (B) led about 2 thousand communists and komsomol members. Other power authorities also sent their representatives. More than 10 thousand visiting agitators participated in the preparation of the election, and 7350 people took part in the work of election commissions [9, p. 236].

At the same time, it is important to note that the organization of the elections itself was not exclusively a matter of the "army of occupation". Local residents comprised 77\% of agitators - 40649 people out of the total amount of 51725 , and $85 \%$ of members of election commissions -41653 persons out of the total number of 49003 [19, p. 125]. According to the official estimates, 4433997 people participated in the elections, hence $92.83 \%$ of those who had the right to vote. Of this number, 4032154 persons, or $90.93 \%$, voted for the candidates to the National Assembly. Soviet propaganda also successfully used the fact that only $46.6 \%$ of voters voted in the elections of the Polish Sejm in 1935 [4, p. 125].

In the Lviv region (former province) out of 1345561 voters, 1232466 people participated in voting, or $91.59 \%$ of all voters. 1088371 people, or $88,30 \%$, participated in the voting, voted for the candidate in the ballot. There were 14631 ballots that were found invalid. There were 129464 ballots in which the names of the candidates were crossed out.

Out of 268382 voters in Lviv, 256802 people participated in voting, or 95.68\% of all voters. 240068 people, or $93.48 \%$, participated in the voting, voted for the candidate in the ballot. There were 1631 ballots, which were found to be invalid, there were 15103 ballots in which the names of candidates were crossed out.

In Tarnopil region (former province) out of 1074387 voters, 945748 or $88.03 \%$ of all voters participated in the voting. 875169 of people or $92.53 \%$, participated in the voting, voted for the candidate in the ballot. There were 33566 ballots that were found invalid. There were 37013 ballots in which the names of the candidates were crossed out.

Out of 27317 voters in Tarnopil, 25493 people participated in voting, or 93.32\% of all voters. 24567 people, or $96.36 \%$ of those who participated in the voting, voted for the candidate in the ballot. There were 382 ballots, which were found to be invalid, there were 544 ballots in which the names of candidates were crossed out.

In Stanislav region (former province) out of 979735 voters, 941830 or $96.13 \%$ of all voters participated in the voting. 877851 people or $93.2 \%$, participated in the voting, voted for the candidate in the ballot. There were 6045 ballots that were found invalid. There were 57934 bulletins in which the names of the candidates were crossed out.

Out of the 27317 voters in Stanislav, 49990 people participated in voting, or $92.72 \%$ of all voters. 43 671 people, or $94.21 \%$ of those who participated in the voting, voted for the candidate in the ballot. There were 42 ballots, which were found to be invalid, there were 2640 ballots in which the names of candidates were crossed out.

In Lutsk region (former province) out of 1376592 voters, 1313953 or $95.44 \%$ of all voters participated in the voting. 1190763 people or 90.62\%, participated in the voting, voted for the candidate in the ballot. There were 21683 ballots that were found invalid. There were 101507 ballots in which the names of the candidates were crossed out.

Out of 31075 voters in Lutsk, 28431 of people participated in voting, or $91.49 \%$ of all voters. 26308 people, or $92.53 \%$ of those who participated in the voting, voted for the candidate in the ballot. There were 170 ballot, which were found to be invalid, there were 1953 bulletins (ballots) in which the names of candidates were crossed out. 
Red Army soldiers, commanders and political workers of the Ukrainian Front units, located on the territory of Western Ukraine, did not take part in the voting.

Out of 1484 elected deputies, there are 1245 men and 239 women [10, p. 39-42].

The first meeting of the National Assembly of Western Ukraine took place in Lviv on the $26^{\text {th }}-28^{\text {th }}$ of October 1939. The deputies approved a declaration on the establishment of Soviet power throughout the territory of Western Ukraine and its entry into the Ukrainian SSR. In the "Declaration of the People's Assembly of Western Ukraine on the Establishment of Soviet Power in Western Ukraine" dated from October 27, 1939, it was reported:

"By revealing the unanimous will of the liberated people of Western Ukraine, following the example of the people of the Soviet Union, the Ukrainian People's Assembly proclaims the establishment of the Soviet power throughout western Ukraine. From now on, all power in Western Ukraine belongs to the working people of the city and the village in the person of the Soviets of Deputies of Workers'” [11, p. 30].

And in the "Declaration of the People's Assembly of Western Ukraine on the Entry of Western Ukraine into the Ukrainian Soviet Socialist Republic", on October 27, 1939, it was stated:

"Ukrainian People's Assembly, as an expression of the unwavering will and aspirations of the people of Western Ukraine, adopts:

To ask the Supreme Soviet of the USSR to accept Western Ukraine as a member of the Union of Soviet Socialist Republics, to include Western Ukraine as a part of the Ukrainian Soviet Socialist Republic, and to unite the Ukrainian people in a single country, to end the eternal separation of the Ukrainian people“ [11, p. 32].

On the $1^{\text {st }}$ of November 1939, the extra fifth session of the Supreme Soviet of the USSR, after hearing the statement of the Commission of the People's Assembly of Western Ukraine, adopted the Law approving the request of the National Assembly of Western Ukraine and the inclusion of Western Ukraine in the USSR, uniting it with the USSR.

On the $29^{\text {th }}$ of November 291939 , the Decree of the Presidium of the SupremeSoviet of the USSR on the receiving the Soviet citizenship by residents of western Ukraine was adopted - a step that had special legal consequences for thelocal citizens. Thus, the inhabitants of western Ukraine were granted equal rights and responsibilities with other citizens of the USSR: they began to receive Soviet degrees and awards, run for offices of local and central authorities, etc. The voluntary use of their civil rights and the silent consent to perform the duties were treated by the Soviet authorities as proof of the will of the entire Western Ukrainian population to "unite" and "to have socialist path of development" [4, p. 130].

On the $4^{\text {th }}$ of December 1939, (there was issued )the Decree of the Supreme Soviet of the USSR “On the formation of the Volyn, Drohobych, Lviv, Rivne, Stanislav, Tarnopil regions as a part of the Ukrainian SSR" was issued. This document affirmed the formation of the following areas in the Ukrainian SSR:

1. Volyn region with center in Lutsk.

To include the following in Volyn region: Lutsk and the districts: Volodymyr-Volynskyi, Gorokhiv, Kamin-Kashyrskyi, Lutsk, Lyuboml with the inclusion of the settlements of Bobrynskyi and Drogychynskyi districts of the Belorus SSR, which became part of the Ukrainian SSR to the KaminKashirskyi district.

2. Drohobych region with center in Drohobych city.

To include the following in Drohobych region: Drohobych and districts: Drohobych, Dobromil (in the new borders), Zhydachiv, Lyskovets (in the new borders), Mostyska, Peremyshl, Rudkiv, Sambir, Stryi, Turka.

3. Lviv region with a center in the city of Lviv.

To include the following in Lviv region: Lviv and districts: Bibrka, Brody, Gorodok, Zhovkva, Zolochiv, Kamensky, Lyubachiv (in the new borders), Lviv, Peremyshliany, Rava-Russka, Radekhiv, Sokal, Yavoriv.

4. Rivne region with a center in the city of Rivne. 
To include the following in Rivne region: Rivne and districts: Dubno, Zdolbuniv, Kostopil, Rivne, Sarny, with the inclusion of the Pinsk and Stalin districts of the Belorus SSR, which were settled (became part of the Ukrainian SSR.

5. Stanislav region with a center in Stanislav.

To include the followingin Stanislav region: Stanislav and districts: Gorodenka, Dolyna, Kalush, Kolomyia, Kosiv, Nadvirna, Rogatyn, Snyatin, Stanislav, Tlumach.

6. Tarnopil region with center in Tarnopol.

To include the following in to Tarnopol region: Tarnopol and districts: Berezhany, Borshchiv, Buchach, Zalischytsky, Zbarazh, Zboriv, Kremenets, Kopychyntsi, Podhaitsi, Skalat, Tarnopol, Terebovlia, Chortkiv [12, p. 37].

Their total territory am ounted to 88 thousand sq. $\mathrm{km}$. It was home to 8 million people, including 7.5 million Ukrainians [13, p. 24].

By Decree of the Presidium of the Supreme Soviet of the USSR from the $24^{\text {th }}$ of December 1939, the Decree of the Supreme Soviet of the Ukrainian SSR "On the delimitation of regions between the Ukrainian Soviet Socialist Republic and the Belarusian Soviet Socialist Republic" was approved from the $27^{\text {th }}$ of November 1939.

On the $7^{\text {th }}$ of March 1940, the People's Commissar of Internal Affairs of the USSR L. Beria sent a directive to the border troops of western District to begin the preparations for the eviction of residents of the border line. The transmigration had to be completed by the $20^{\text {th }}$ of April, and resettlement - by May 1940. According to the plan of eviction from the border line in western regions of the Ukrainian SSR in April-May 1940, it was foreseen to transmigrate 80185 and resettle 22615 people. The eviction of more than 100 thousand people reminded the military operation of the border troops under the leadership of the party and the Soviet authorities. Its organizational unit was personally assigned to the secretaries of the regional executive committees and secretaries of the regional committees of the CP (b) in western regions. Leaders of the border units and troops provided them with a variety of support. Roles were distributed during the meeting in Lviv on the $13^{\text {th }}$ of March by the head of the CPC of the Ukrainian SSR L. R. Korniets. It was foreseen to provide the rail and road transport, transport of buildings, and financial assistance to the settlers. It was a passive, preparatory stage of resettlement, primarily related to the need to refrain from negative affect on the social mood of western Ukrainian population before the elections to the Supreme Soviets of the USSR and the Ukrainian SSR, scheduled for Sunday, the $24^{\text {th }}$ of March. Its active stage began in April.

On the evening of the $7^{\text {th }}$ of April 1940, the new western border of the USSR was tightly blocked with the occupied bays and manoeuvre groups. The party and Komsomol assets of the border units mobilized for the deployment of explanatory work among the population to prevent the outbreak of anti-Soviet demonstrations. Such work was to convince the need to strengthen the border and the availability of better conditions for farming in that areas [7, p. 115].

The border, which was formed as a result of the division of Poland between the USSR and Germany, divided a lot of relatives and acquainted people. During the resettlement on the Soviet side, residents of the German zone, called the residents of Ukrainian villages to themselves or offered to hide for a while. The NKVD authorities recorded a lot of cases when the Wehrmacht soldiers dispersed the crowds of sympathizers on the territories seized by Germany. In those days, according to the information from the border troops of the NKVD of the Ukrainian SSR, the Soviet-German border was crossed by 124 persons [7, p. 116]. Their number could be larger, but spring floods became insurmountable barriers for people forced to resettle. Fugitives became the largest anti-Soviet agitators. According to their stories, it turned out that western Ukraine was conquered by Russians, that there were no Ukrainians in the Red Army, and the Ukrainian population did not get the expected freedom.

A fast resettlement from the 800-meter board line lasted until the $25^{\text {th }}$ of April 25, when the massive sowing campaign began. Thereafter, due to the lack of means of transportation much less peasants moved to the new places [7, p. 116]. Part of them, having not received the promised land and household buildings, returned to their villages. Administrative pressure was used against the "returnees", about which some of the local newspapers informed implicitly. 
The plan for eviction from the border line was completed at the beginning of June 1940.

Germany started the protection of the border since the $1^{\text {st }}$ of January 1940, at the same time the border regime intensified, although Germans concealed their intentions, denying the existence of a special state on the German-Soviet border.

The USSR began to build its western border a year before the start of the Soviet-Nazi war, having previously negotiated with Germany. On the $10^{\text {th }}$ of June 1940 in Moscow a convention on the procedure for resolving conflicts and incidents at the state border, established by the Soviet-German agreement on friendship and the border from the $28^{\text {th }}$ of September 1939 was signed. The ease and em phasized friendly atmosphere of this and other agreements dem onstrated once again that Hitler had no intention of keeping to them, and that the Soviet side was trying in every possible way to win time [7, p. 117].

On the basis of the decree of the Presidium of the Supreme Soviet of the USSR on the receiving of citizenship of the USSR by residents of western regions of the Ukrainian and Belorusian SSR in the spring of 1940, the passportization of the population began here. Some Poles received passports with so-called $11^{\text {th }}$ paragraph, which restricted freedom of movement and choice of place of residence [7, p. 121].

The first period of the international legal consolidation of administrative-territorial changes in Eastern Galicia lasted from the $17^{\text {th }}$ of August 1939 to the $10^{\text {th }}$ of June 1940. In the second period, between the $30^{\text {th }}$ of July 1941 and the $16^{\text {th }}$ of August 1945, the state-legal status of western Ukrainian lands, according to V. S. Makarchuk, should be considered ambiguous or controversial. He proves this by the fact that the Soviet Union, on its own initiative, announced its readiness to reconsider the line of the prewar western border (the $30^{\text {th }}$ of July 1941), to recognize the Polish citizenship of some of the population of western Ukrainian, Western Belarusian and Lithuanian lands, which had Polish roots, agreed to mobilize them in the ranks of the Polish Army and even promised to pass to Poland all the areas where the ethnographic advantage of the Polish population would be. This was said, in particular, by Stalin in Tehran. On the other hand, in this period, statements about the possibility of settling the territorial issue through the revision of the Soviet-Polish border line of 1939 after the end of the World War II were made by the leaders of the Polish emigrant government (S. Mikolajczyk in March and October 1944) and by the Polish Committee of National Liberation (PCNL) and the Provisional Government of National Unity (PGNU) [4, p. 310].

On the 4-11 th of February 1945 in Yalta, western border of the USSR was determined along the "line of the Curzon" with small biases in favor to Poland, Eastern Galicia was devoted to the USSR, and Belostok - to Poland [13, p. 156]. This border actually existed from 1944, and was officially approved on the $16^{\text {th }}$ of August 1945 by the Polish-Soviet agreement in Moscow. Poland handed over to the USSR all the Ukrainian and Belarusian lands that were part of it at the beginning of the World War II. The border line almost coincided with the "Curzon line" of 1919, although it was slightly changed from it in favor to Poland. Poland retained Przemysl in Galicia, and the Ukrainian SSR annexed Rava-Ruska. East Prussia was divided between the USSR and Poland. The northern part with Königsberg, which became Kaliningrad, was annexed by the USSR, and the southern part was annexed by Poland. It was bordered almost by the Braunsberg-Holdap line. In the west, all the Germ an territories to the east from the Oder, in its downhill and its tributaries of the Nese, or Nysa-Luzhytska, which flows through Zgorzelec (Gorlitsy) and Gubin (Guben), went off to Poland. Port of Stettini (Szczecin), as well as Swinemünde, went to the Poles. Thus Poland gained 524 kilometers of the Baltic coast and controlled the Oder and Wisla (the Vistula) estuaries. It also received Pomerania and Silesia. Its common borders with Germany were considerably reduced. In general, the territory of Poland has decreased from $338,000 \mathrm{sq}$. $\mathrm{km}$ to 310,000 sq. km More than 2 million Germans were evicted from the annexed territories, and the Poles began to colonize their former settlements: about 2 million Poles were repatriated from the territories transferred to the USSR [15, p. 391-392]. The exchange of ratification documents took place only on the $4^{\text {th }}$ of February 1946, and by that time, from the point of view of international law, the border that was defined by the Riga Treaty from the $28^{\text {th }}$ of March 1921 [4, p. 248]. The borders of Poland were moved from east to west for more than $200 \mathrm{~km}$. [16, p. 166]. 
The international-legal consolidation of the Soviet-Polish border was received in a number of Paris Peace treaties from the $10^{\text {th }}$ of February 1947, with Bulgaria, Hungary, Romania, Finland and Italy. The peace treaties confirmed the inclusion of Western Ukrainian lands to the USSR [17, p. 60-61]. The Verkhovna Rada of the Ukrainian SSR ratified these treaties on the $13^{\text {th }}$ of September 1947 [18, p. 337-338].

On the $15^{\text {th }}$ of February 1951, the agreement between the Polish Republic and the USSR on the exchange of areas of state territories, which completed the international legal consolidation of western border of the USSR was signed. The parties exchanged the territories with the total area of $480 \mathrm{sq} . \mathrm{km}$ The territory of the Ukrainian SSR included the Belz and Sokal districts, and Poland received the territory of the same size in the area of Ustrzyki Dolne. This allowed the USSR to open several new coal mines near Krystynopol (Chervonograd); and Poland - to build a dam in Solin on the Sian, as well as to complete the development of almost exhausted oil fields in the specified area [4, p. 285-286].

Thus, in the opinion of V. S. Makarchuk the international legal consolidation of administrativeterritorial changes in Eastern Galicia in the terms of the World War II can be divided into three stages:

- at the first stage, which lasted from the $17^{\text {th }}$ of August 1939 until the $10^{\text {th }}$ of June 1940, the stateterritorial status of the West Ukrainian lands was determined, western border of the USSR was outlined because of the entry of western Ukraine to the Ukrainian SSR and the USSR;

- at the second stage, covering the period from the 30 ${ }^{\text {th }}$ of July 301941 until the $16^{\text {th }}$ of August 1945, the state-legal status of western lands due to the World War II became uncertain;

- at the third stage, which lasted from the $16^{\text {th }}$ of August 1945 to the $15^{\text {th }}$ of February 1951, the final international legal consolidation of western border of the USSR and the state-territorial status of the West Ukrainian lands took place.

These three stages can be reduced to two, bringing the periodization of the process of international legal consolidation of the state-territorial status of Western Ukrainian lands with the periodization of the process of their sovietization into conformity. The first stage in this case takes the period from the $17^{\text {th }}$ of August 1939 to the $10^{\text {th }}$ of June 1940, and the second one - from the $16^{\text {th }}$ of August 16 to the $15^{\text {th }}$ of February 1951.

\section{REFERENCES}

[1] Kosyk V. Ukraine and Germany in the Second World War. NTSh, Lviv, 1993. (in Ukrainian)

[2] Zastavnyi F.D. Geography of Ukraine. Svit, Lviv, 1994. (in Ukrainian)

[3] Kulchytskyi V.S., Tyschyk B.Y. History of the State and Law of Ukraine. Atika, Kyiv, 2001. (in Ukrainian)

[4] Makarchuk V.S. State and Territorial Status of Western Ukrainian Lands during the World War II (19391945). Historical and Legal Research. Atika, Kyiv, 2007. (in Ukrainian)

[5] Grynevych V.A. Red Army in the wars and military conflicts of 1939-1940: military-political, ideological and socio-psychological aspects. Issues of History of Ukraine: Facts, Opinions, Search, 10 (2003), 340-372. (in Ukrainian)

[6] Koval V.S. Soviet-German Pact of 1939. Institute of History of the USSR, Kyiv, 1989. (in Ukrainian)

[7] Danilenko V.M. The liquidation of the Polish state and the establishment of the Soviet regime in Western Ukraine. Ukrainian Historical Journal, 3 (2006), 111-125. Available at: http://resource.history.org.ua/publ/journal_2006_3_111 (in Ukrainian)

[8] Kondratiuk K., Kondratiuk S. Formation and nature of Soviet power in western Ukraine (September 1939-June 1941). "Naukovyi i kulturno-prosvitnii kraieznavchyi chasopys "Halychyna", 5-6 (2001), 347-356. (in Ukrainian)

[9] Soroka Y.M. Formation of the Soviet totalitarian system in western Ukrainian lands. 1939 - 1941. Bulletin of Taras Shevchenko National University of Kyiv. History, 77-79 (2005), 136-138. (in Ukrainian) 
[10] Gudzenko P. (Ed.) Reunification of the Ukrainian People in the United Ukrainian Soviet State (1939 - 1949). Derzhpolitvydav URSR, Kyiv, 1949. (in Ukrainian)

[11] Soviet Subcarpathian 1939 - 1959. Documents and Materials. Karpaty, Uzhgorod, 1964. (in Ukrainian)

[12] Yaremchuk D.A. Socialist Transformations in Western Regions of the Ukrainian SSR. 1939 - 1979. Naukova Dumka, Kyiv, 1980. (in Ukrainian)

[13] Velykochyi V.S. Galicia in the World War II. Plai, Ivano-Frankivsk, 2001. (in Ukrainian)

[14] Gregory P. The Political Economics of Stalinism. ROSSPEN, Moscow, 2008. (in Russian)

[15] Duroselle J.B. Histoire Diplomatique de 1919 à Nos Jours. Translated into Ukrainian by Marichev Ye. (et al.). Osnovy, Kyiv, 1995. (in Ukrainian)

[16] Dylągowa H. Historia Polski 1795-1990. Translated into Ukrainian by Kirsenko M. Publ. House "KyivMohyla Academy", Kyiv, 2007. (in Ukrainian)

[17] Potemkin V.P. History of Diplomacy; Vol. 5. Politizdat, Moscow, 1974. (in Russian)

[18] Kolotukha Y.Y. (Ed.), Burchak F.G. Collection of Laws of the Ukrainian SSR and Decrees of the Supreme Soviet of the Ukrainian SSR. 1938-1973. Politvydav, Kyiv, 1974. (in Ukrainian)

[19] Varetskyi V.L. Socialist Transformations in the Western Regions of the Ukrainian SSR (pre-war time). AN URSR, Kyiv, 1960. (in Ukrainian)

Address: Andriy Redko, Vasyl Stefanyk Precarpathian National University, 57, Shevchenko Str., IvanoFrankivsk, 76025, Ukraine.

E-mail: anred2008@ukr.net

Received: 17.07.2018; revised: 08.11.2018.

Редько Андрій. Західна Україна в контексті дезінтеграційно-інтеграційних процесів 30-40рp. XX ст. (історико-правовий аспект). Журнал Прикарпатського університету імені Василя Стефаника, 5 (3-4) (2018), 62-69.

В статті досліджуються дезінтеграційно-інтеграційні процеси в Центральній і Східній Європі та їх вплив на правовий статус Західної України. Дезінтеграція співвідноситься з радянською окупацією Західної України, інтеграція із процесом їі входження до складу СРСР.

Шияхом виокремлення етапів зазначених процесів концептуалізується історико-правовий вимір України в європейському контексті.

Ключові слова: Західна Україна, Польща, СРСР, дезінтеграція, інтеграція, правовий статус. 